\title{
Should They Stay or Should They Go? \\ A discourse analysis of factors influencing relocation decisions among the outer islands of Tuvalu and Kiribati
}

\author{
Roy Smith \\ Nottingham Trent University ${ }^{1}$
}

\begin{abstract}
The low-lying atoll states of Tuvalu and Kiribati have gained international attention due to their vulnerability to climate change and associated sea-level rise. They have been referred to as 'sinking islands', with some commentators predicting they could become completely uninhabitable within a generation. This work acknowledges that climate change is having a negative impact on these island communities. However, it would be too simplistic to only focus on this as the key factor in patterns of migration from the outer islands to the urban centres of each state. There are multiple drivers for both internal and international migration, and also for the desire to reside in these communities for as long as they remain habitable. Through fieldwork interviews with residents of Vaitupu, an outer island of Tuvalu and Abaiang, an outer island of Kiribati, this work seeks to understand the key determinants in residents deciding whether or not to relocate. Interviews were also conducted with former members of these communities that are now resident in the respective urban centres of Funafuti and Tarawa. Further context was supplied via interviews with government officials, donor agencies and civil society groups.
\end{abstract}

Keywords: climate change, discourse analysis, migration, relocation, Kiribati, Tuvalu

1 This work was partially supported by research funding made available by the School of Arts and Humanities, Nottingham Trent University. Support was also offered by the EU-USP Global Climate Change Alliance project, which helped to facilitate the fieldwork elements in both Tuvalu and Kiribati. Particular thanks are due to Sarah Hemstock, Project Director for GCCA at USP and Karen McNamara for their comments on earlier drafts of this work. 


\section{Background and study objectives}

The Pacific island state of Tuvalu has a population of approximately 11,000 with half of this number living in the main urban centre of Funafuti. It has a total land area of only 26 square kilometres, which ranks it as the fourth smallest state in the world. However, it has a vast exclusive economic zone in excess of three quarters of a million square kilometres. Kiribati has a similar land to ocean area ratio with an exclusive economic area of close to three and a half million square kilometres. Kiribati's total population is slightly over 100,000 of whom, again, roughly half live on the main island of Tarawa. Both island states are made up of several atolls and islets with marked concentrations of their citizens based in the administrative capitals. Tuvalu and Kiribati face particular development challenges in terms of their relatively limited land-based resources, difficulties in accessing and capitalising on their marine-based resources, distance from markets and high importation and transport costs. They have also been described as being on the 'front line' with regard to the negative impacts of climate change and sea-level rise.

The vulnerability of coastal communities and low-lying atoll states to the impacts of climate change and sea-level rise has been recognized for the last two decades. This was demonstrated by the formation of the Alliance of Small Island States (AOSIS) prior to the Earth Summit held in Rio de Janiero in 1992. Since this landmark meeting there have been regular international conferences aimed at promoting sustainable development and highlighting the species and communities most at risk from changing climate and weather patterns. A growing body of literature has focused on the low-lying atoll states, notably Tuvalu and Kiribati, as being at risk from climate change. (see Barnett and Campbell, 2010; McNamara and Gibson, 2009; Mimura et al., 2007; Patel, 2006; Barnett and Adger, 2003).

At the 2009 Copenhagen Conference of Parties to discuss the United Nations Framework Convention on Climate Change (UNFCCC), the representatives of Tuvalu and Kiribati argued strongly for the need to limit global temperature warming to $1.5^{\circ} \mathrm{C}$. Simultaneously the international scientific congress on climate change contended that 'warming above $2^{\circ} \mathrm{C}$ would be very difficult for contemporary societies and ecosystems to cope with' (Climate Congress, 2009). There is now broad agreement that warming beyond $2^{\circ} \mathrm{C}$ is likely and will result in numerous negative impacts on societies and ecological systems across the world, especially for low-lying coastal communities (Parry et al., 2009; Smith et al., 2009). These communities will have to contend with a series of interconnected impacts, such as declining freshwater and food security and diminishing land availability, as a result of sea-level rise and an increasing number of extreme weather events (Adger and Barnett, 2009).

As Hayward-Jones (2010: 2) predicted: 'What is at stake over the next decade is not a sinking island but the very viability of life on this fragile atoll state. The landmass of Tuvalu will still exist in 2020 but it may be unable to support the population'. This statement is representative of many of the more dramatic interpretations of future scenarios for both Tuvalu and Kiribati. Migration is often seen as unavoidable as environmental degradation, particularly with regard to freshwater resources, leads to an inability for these communities to remain selfsufficient and viable. However, such analyses tend to overlook the strength of attachment communities feel to their homeland, and also the ability of communities 
to continue to reside in areas where they are more reliant on imported foodstuffs than on what they are able to produce locally. In some respects it is surprising the latter point is overlooked as the majority of the world's population now live in urban as opposed to rural environments and are far from self-sufficient. Clearly access to drinking water is an essential resource, but the ability to produce food crops is less of an issue if communities have the means to purchase imported food. It should also be noted that reliance on imported, processed food does have considerable implications for health and Pacific island communities have some of the highest levels of non-communicable diseases such as obesity, heart disease and diabetes (Smith and McMurray, 2000)

This study is designed to look beyond the externally created and imposed stereotype of 'sinking islands' and ask the people most impacted by sea-level rise how they perceive the changes to their environment and how they are adapting to these changes.

\section{Methodology}

The key respondents in this study were the participants in two community workshops organised as part of the European Union / University of the South Pacific's Global Climate Change Alliance project. These took place in Tuvalu and Kiribati during November and December 2012. In addition to the workshop programmes this project also conducted household surveys in the outer islands of each state. The intention was to gather a broad range of responses at the community level with regard to how the impacts of climate change were perceived locally and what adaptation measures were being identified and implemented. Although climate change was an underlying theme throughout these workshops and surveys, it quickly became apparent that this was only one among many factors that the islanders in these communities took into account when considering possible relocation to the capital urban centres, or further overseas.

Much of the mainstream media coverage of Tuvalu and Kiribati focuses almost entirely on the threat of sea-level rise. A rare exception to this was the 2012 royal visit of the Duke and Duchess of Cambridge to Tuvalu. Even then virtually every report mentioned Tuvalu's situation in relation to climate change. The discourse on climate change has led Tuvalu and Kiribati to become synonymous with the threat of sea-level rise, at least for those outside of these states. The view from within these communities is, understandably, quite different. Several respondents reacted forcefully to the 'sinking islands' stereotype and suggested that this was an unnecessarily negative and pessimistic portrayal of their communities. By reducing representations of themselves to 'helpless victims' of climate change they were concerned that this limited how the rest of the world both viewed and, therefore, valued their culture and future. There was a particular objection to the term 'ecorefugee' as there was a sense that the term 'refugee' has negative connotations. If relocation were to be an option of last resort then the islanders would want to be seen in a positive light by whichever state and society they might migrate to.

With regard to the methodology employed for this study this is a very complex topic, which has been looked at from various perspectives. Jane McAdam (2011, 2012) has focused on the international legal dimension of possible relocation, with a particular focus on the use of the term refugee. This is an important dimension of 
the topic but one that provides context rather than directly informs this work. Similarly there is a growing body of literature looking at how sovereignty as a concept is being challenged by various processes of globalisation, for example the work of Jean Cohen (2012). Again, this has relevance to the communities in question in terms of potential future scenarios where mass migration may become necessary and this will raise questions regarding the ability of these states to maintain their current level of statehood and sovereignty. This is, literally, an existential question and one that cannot be ignored when discussing possible futures for these communities. That said, all of the respondents, including government officials, emphasized that such scenarios are almost 'unthinkable' and they much preferred to focus on measures to remain as communities within their current sovereign territories. Some statements by President Tong of Kiribati have suggested that relocation should be seen as a realistic policy option, but this is a position not currently shared by other Pacific Island governments.

Although the above points on relocation and potential refugee status are always going to have some bearing on any discussion on climate change and sea-level rise, this study seeks to acknowledge these issues but also make it clear that this should not be the light that casts shadows on the many other factors that contribute towards patterns of domestic and international migration. In terms of a theoretical approach to inform the chosen methodology discourse analysis is appropriate as it takes into consideration the dominant discourse as 'imposed' by external commentators including, but not exclusively, print and broadcast media. It also places an emphasis on hearing the 'voices' of the various respondents with recognition of how they are viewing their own identities and situations, which is often at odds with popularised, shorthand stereotypes. In particular this study draws on the work of Teun A. van Dijk (2008a, 2008b, 2009)

\section{Tuvalu}

The Tuvaluan delegation to the UNFCCC Conference of the Parties meeting in Copenhagen in 2009 gained worldwide media attention when they castigated the major industrialised states for their lack of progress in cutting greenhouse gas emissions and other mitigation measures. Environmental organisation such as Friends of the Earth and Greenpeace International were quick to capitalise on this and to align themselves with Tuvalu's position in the negotiations. Protesters at the meeting held placards saying 'We are all Tuvaluans', both in a sense of solidarity with the Tuvaluan delegation but also to demonstrate that what was happening to Tuvalu was a microcosm of global trends that highlighted the environmentally damaging impacts of capitalism and fundamentally unsustainable patterns of mass consumption. Here the discourse on the future of Tuvalu, if not hijacked, was at least co-opted in order to further the broader arguments of the international environmental movement.

The above actions were welcomed in Tuvalu as they drew attention to the impacts of climate change and helped the case for development assistance to build resilience and to fund adaptation strategies. However, as indicated above, although the old adage of there being no such thing as bad publicity generally holds true, such action did have some unintended consequences. Chimamanda Adichie has warned of the danger of a single story. 'The single story creates stereotypes, and the problem with stereotypes is not that they are untrue, but that they are incomplete. They make one 
story become the only story' (Adichie, 2009). Her example referred to the dominant discourse in relation to Africa, with its focus on famine, disease and armed conflicts. She argued that despite there being some truth within this story it was a very selective misrepresentation of the continent. Both Tuvalu and Kiribati are often portrayed via the single story of expected relocation due to climate change. As with representations of Africa there is some truth in this story, but it is incomplete and, therefore, misleading.

Interviews undertaken in Tuvalu fell into three categories. At the government level interviews were conducted with the Prime Minister, Willy Telavi, and Apisai Ielemia, the Minister for Foreign Affairs, Trade, Tourism, Environment and Labour, who is also a former Prime Minister. Interviews were also held with representatives of AUSAID, NZAID and the European Union as development aid donors operating in Tuvalu. At the civil society level interviews were conducted with members of various non-governmental organisations, including the Chair of the Tuvaluan Association of Non-Governmental Organisations (TANGO). The EU-USP GCCA workshop included participants from each of Tuvalu's inhabited atolls and was, therefore, an opportunity to interview residents from each of these outer island communities. This also led to further interviews with family members of these respondents, who had already relocated to the main atoll of Funafuti.

At the government level both the Prime Minister and Foreign Minister expressed concerns regarding their perception of how the international discourse on climate change has evolved in recent years at the UNFCCC negotiations and related meetings. They drew attention to key words in the discourse beginning with the Earth Summit of 1992 and an emphasis on the 'vulnerability' of small island developing states. This was criticised as being a somewhat negative term that implied a lack of agency among these states and a sense of them as powerless victims. Whilst there is a large amount of truth in these states possessing a relative lack of power and agency in relation to the major industrialised powers criticisms of the use of the word vulnerability were acknowledged by the UNFCCC signatories. By the turn of the century the discourse had shifted to the seemingly more positive use of 'resilience' as a key term. Clearly this did not alter the fundamental power differential between the small island states and the major industrialised powers. Yet both Ministers felt that this was a significant turning point in how Tuvalu and other Pacific islands were not only viewed, but also how they saw themselves in relation to each other and the rest of the world.

Another important shift in the use of language and discourse in climate change negotiations has been a move from emphasising 'mitigation', which has its focus on reducing the causes of climate change, to 'adaptation'. The significance of this is twofold. First, it suggests that mitigation measures are, if not completely failing, at least operating at too slow a rate to halt or reverse current climate change patterns and trends. Second, by moving the discourse to focus more on adaptation this puts the onus on the communities most impacted upon to adapt to their changed circumstances. The Ministers both highlighted the move from mitigation to adaptation as a notable change in discourse with some marked practical implications for Tuvalu. From their perspective this change in use of language was driven by the major powers and represented an implicit recognition that mitigation measures to date have been inadequate. They feared that whereas mitigation was a 
clear mandate to reduce greenhouse gas emission, adaptation could be interpreted in many different ways. For them the worst case scenario was for the industrialised powers to continue to produce greenhouse gasses but attempt to off-set any dissent and protest from states such as Tuvalu by 'buying them off' with adaptation aid packages. In the most extreme future scenario this could mean assistance to relocate as the various islands of Tuvalu become increasingly uninhabitable.

The issue of relocation is something that is an underlying concern for many of the groups associated with the umbrella organisation TANGO. Its main office is situated close to the airport runway in Funafuti and is regularly surrounded by water during high tides. Annie Homasi is the coordinator of this group and part of her remit is to engage with communities living in the outer islands of Tuvalu. She referred to climate change as an issue for some of these communities mainly in terms of diminishing freshwater resources as wells and taro pits became salinated during high tides. This has implications for supplies of drinking water and also for crop cultivation. The nature of TANGO is such that it encompasses a diverse range of groups that focus on environmental sustainability, public health and an array of development projects. In some instances TANGO acts as the conduit for the delivery of overseas development assistance. It is also in a good position to have a broad overview of the situation in the outer islands and what factors are involved in the dynamics of any relocation to Funafuti, or beyond.

The 'single story' of Tuvalu from an external perspective is quite different at the local level. TANGO's experiences suggest that although there are climate changerelated issues, such as water and food security, among the outer island communities these are not necessarily the key motivators for any out migration. More likely motivators are for education and job opportunities or to join family members that have already relocated. Importantly TANGO's membership includes residents of the outer islands and Homasi was very clear in stating that these individuals and communities would much prefer to maintain the majority of their traditional lifestyles where they currently reside. She also noted that it would be wrong to think of the outer islands and the main island of Funafuti as wholly separate and distinct communities. Many of those currently residing in Funafuti continue to identify themselves as being from Vaitupu, Nanumea or one of the other outer islands. There is also an informal system of remittances being sent to these communities from family members in Funafuti and those working overseas. Because these transactions are not formally monitored and recorded, the amounts involved are difficult to quantify. With this income stream being available to buy imported food and other goods there is less of a need for the outer island communities to choose between maintaining their traditional subsistence practices or to relocate to the main island. This issue of external support to encourage these communities to remain where they are is also something that is relevant to the international donor community.

International aid packages can be divided into large-scale infrastructure projects, household level assistance (such as the provision of rainwater harvesting systems and storage tanks) and health and education assistance aimed at individuals. Investigating the longer-term commitment of the international donor community provides some insight into how they view the likelihood of these communities remaining where they are. There would be little incentive or cost-effectiveness in 
directing long-term funding to communities that may well be relocating in the short to medium term. Eventually a tipping-point would be arrived at whereby any funding would be better spent in assisting with the relocation process. The donor representatives interviewed from AUSAID, NZAID and the EU had a shared position on this point. Informally it was recognized that relocation may be something that they would be expected to assist with at some point in the future. This is not yet stated as a formal aid assistance policy. At best Australia and New Zealand have indicated that they are looking at increasing the number of migrants they accept each year from the Pacific Islands. Migrant worker schemes are also being reviewed, but these are for temporary work contract rather than leading to permanent settlement.

The Australian government is contributing US\$ 3.19 million towards the World Bank-managed Pacific Islands Investment Program. This includes a relocation and upgrade of the terminal facilities at Tuvalu's main Bonriki Airport in Funafuti. This is a significant investment and one that suggests Australia, at least, is anticipating Tuvalu will require this airline link to be maintained for a reasonable period of time. A major infrastructure investment such as this would not be committed to unless some return in this investment was anticipated. The more alarmist predictions that are such a large part of the discourse related to Tuvalu and climate change might appear, therefore, to be somewhat exaggerated. This is not to underestimate the real and present danger that some of these communities are facing from storm surges, inundation and the loss of productive land. Rather, the ongoing investment from various international donor agencies indicates that, notwithstanding these localised environmental crises, their broader assessment is of Tuvalu as a viable state for the foreseeable future. This is certainly the case for the main urban centre of Funafuti, but may not necessarily apply to the same extent for some of the outer island communities.

Models of development assistance tend to focus more on supporting the government and business hubs of capital cities and their surrounding environs. Much of the development assistance in Tuvalu, and most Pacific Islands, is focussed on capacity building within government administrations. Bertram and Watters have characterised many of the Pacific islands economies as being based on aspects of migration, remittances, aid and bureaucracy or MIRAB economies (Bertram and Watters, 1985; Bertram, 1999 and 2006). This model, either by design or default, favours the capital cities and encourages the process of urban drift. It also highlights the differences between the more traditional, self-sufficient rural communities and the modernised import-dependent urban areas. The issue of urban drift was one that formed a consistent theme when discussing possible relocation from Tuvalu's outer islands to the main island of Funafuti.

The discourse that views Tuvalu as a 'sinking island' uses very broad brushstrokes and sweeping generalisations about the presumed demise of these islands. Of course the human impacts as a result of climate change and sea-level rise is felt at the level of the individual. Therefore, it is necessary to focus at this level to gain a clearer understanding of not only what is actually happening among the outer island communities, but also how the islanders there perceive these impacts and how they are responding. 
Interviews with individual islanders revealed some variation in their personal circumstances, outlook and feelings towards their possible futures. This is to be expected but there was also a remarkable convergence and similarity in relation to their views on the causes and consequences of climate change and how they might adapt to them. Climate change denial appeared to be non-existent as an attitude with every respondent recalling changes that they had personal experience of. This was, understandably, more marked among the older respondents. The age range of respondents was 16 to 85 years old, but even the youngest among them recounted stories of coastal erosion, loss of coconut and pandanus trees and cultivation pits becoming unproductive. Whilst many attributed these losses to more extreme weather events there was also recognition that some coastal erosion was exacerbated by factors such as the building of wharves, sea-walls and other construction projects. This is an important point as it both acknowledges that while parts of the broader discourse on climate change have some elements of truth, there are also other very important factors to be taken into account at the local level. From this perspective there is no contradiction in arguing that climate change may be having a negative impact on these communities, but there are also other factors that the islanders do have some agency over and could alter local practices to lessen the negative impacts of climate change.

The above local level insights into the perceptions of and responses to climate change are crucial in gaining a clearer understanding of outer islanders' motivations for either remaining in these communities or seeking relocation. Also, it is not until questions are asked at this level that certain types of information is revealed that is not immediately apparent from outside of these communities. For the majority of external observers Tuvalu's situation is viewed in terms of rising sea-level and an increasing inability to be self-sufficient in crop production. The assumption is, therefore, that if this situation deteriorates still further then the 'push' factor will be such that relocation will become inevitable. What this fails to take into account is the strength of attachment and emotional ties that bind these communities together, and in specific locations. For example, one respondent spoke of their inability to leave their parents and grandparents behind if they were to relocate. At first it was assumed these were living relatives, but the graves of three generations of this family were on the relatively small plot of land occupied by this household. This is culturally distinct from many Western societies who deal with death in a very different manner and assign relatives' remains to graveyards some distance from the household. Tuvaluan grave sites are often immediately next to living areas and it is common to see items of food, drink or other memorial artefacts left on graves in remembrance of deceased family members. Several respondents referred to visiting and speaking with ancestors when they were having difficulties and in need of advice and guidance.

This 'pull' factor of attachment to specific land area does not only apply to those that are permanent residents in outer island villages. In discussions with former residents of Vaitupu and other outer islands who are now resident in the main island of Funafuti it was clear that they still felt a very strong sense of attachment to what they described as their 'home island'. They also reported that this feeling was something that would be recognized by Tuvaluan Diaspora now living in New Zealand or further overseas. In part this may go some way towards explaining the level of remittances which form a small but significant part of the outer island 
economies and purchasing capabilities. Extended family relations across multiple locations, for example Vaitupu, Funafuti and Auckland, are common. This facilitates ongoing ties among and between family groups. Physical travel between these locations are limited due to prohibitive air fares and other costs. However, improvements in information and communication technologies have helped to maintain and reinforce these links.

One significant distinction in response to questions about climate change and possible relocation was a variance along generational lines. Older respondents were more likely to highlight environmental changes they had witnessed, but were also the least likely to consider relocation as a possible future for themselves. In contrast younger respondents appeared more open to relocation from the outer islands to Funafuti and possibly further overseas. In part this can also be explained by the perceived likelihood of being able to move. Older respondents would be less likely to find education and employment opportunities. There is already a marked demographic pattern in many of the outer island villages with young adults being the generation that are currently in Funafuti or overseas undertaking training or employment. These are often courses or work contracts for a limited period of time, although some may lead to more permanent employment and possible residency away from their home island. Pursuing education and work opportunities were cited far more as factors which may encourage people to relocate then specific climate change-related issues. Again this highlights a significant difference in discourse between how relocation decisions are understood and arrived at depending on a poorly informed 'single story' narrative and one that takes into account a wider range of local socio-cultural and economic factors.

\section{Kiribati}

The interviews conducted in Kiribati followed a similar pattern to those in Tuvalu. These also involved government officials, representatives of donor agencies and NGOs plus individual I-Kiribati who either resided in outer islands or had moved from there to the capital island of Tarawa.

Tuvalu and Kiribati are often jointly cited as being at risk from climate change and sea level rise but it is important to note that there are important differences between the two states. Whilst they do share some topographical features in that they both comprise of low-lying coral atolls the population of Kiribati is ten times that of Tuvalu, and spread over an even greater expanse of ocean. Tarawa faces even greater strain on its urban infrastructure than Funafuti with a population of approximately fifty thousand, of whom only half have mains water supply and sanitation facilities. Despite some challenging living conditions the population of South Tarawa in particular is continuing to grow. This is partly due to a relatively high birth rate but also as there in ongoing in-migration from the outer islands. It should be noted though that some of this in-migration is temporary as outer islanders move to Tarawa for study and employment opportunities. Usually they would move in with family members already residing in Tarawa, thereby maintaining and reinforcing familial links with outer island communities.

Kiribati has also set itself apart from Tuvalu and other Pacific island nations by way of some of President Tong's speeches to the UN and on other international 
platforms where he has indicated that Kiribati is preparing for a time when the population will need to relocate. Some external commentators have read this as a move towards mass relocation of the whole of the population. However, a closer reading of the President's comments indicate that he is talking about training and up-skilling I-Kiribati to enable them to entering job markets elsewhere 'on merit'. This is something that resonates with the Tuvaluan resistance to the term 'refugee' mentioned above. Being able to find employment outside of Kiribati is not impossible, although with the current downturn in the global economy employment opportunities are likely to be restricted, especially for someone entering a country that is unlikely to have full employment for its own nationals. While President Tong may have highlighted a possible solution for a small number of his citizens this will not be practical for the vast majority. Mass migration would also involve considerably more people than if Tuvalu were to follow a similar course of action. Accommodating ten thousand migrants in Australia or New Zealand would be a political challenge for either government where immigration and race relations have often been the subject of controversy and a lightening rod for some of the minor but vocal elements in both states' electorates.

In an interview with Tessie Lambourne, Kiribati's Secretary for Foreign Affairs and Immigration, she did not attempt to distance herself from President Tong's position, but she did provide a more realistic assessment of how many of the population would be willing and able to take up such relocations. While she acknowledged that some, particularly younger, I-Kiribati would want to explore studying and working abroad she expressed a belief that the vast majority of the population would not. She made a distinction between relocation from the outer islands to Tarawa and migration overseas. Although a strong sense of communal identity can still be identified among I-Kiribati Diaspora, Secretary Lambourne's view was that most aspirations for study and employment could be met in Tarawa without the need to venture to other states. As with the Tuvaluan experience the practicalities of maintaining relatively close associations with home villages was more manageable from within the state rather than the prohibitively expensive overseas travel.

On the discourse of climate change at the international level Secretary Lambourne reiterated the Tuvaluan Ministers' reservations about the apparent shift in emphasis from mitigation to adaptation. She was slightly more optimistic in hoping that both pathways could be pursued simultaneously. A dominant focus on adaptation measures does not necessarily mean that mitigation policies are completely ignored. For her the issue of climate change was something that could not be ignored and there is clear evidence of the negative impacts it is having not just among the outer island communities but also on Tarawa itself with areas such as Golden Beach experiencing regular tidal flooding. Yet this was not seen as the priority area for government action. More immediately there was a need to address some basic infrastructure weaknesses, particularly in the areas of water, sanitation and provision of electricity. For those outside of Kiribati who believe in the 'sinking islands' scenario it may seem strange that climate change is not necessarily viewed as the number one priority. Tidal flooding is, by definition, cyclical. It does create a degree of inconvenience in that it restricts movement, and it does have an impact on the ability to grow crops. That said, the residents of Golden Beach are generally not living subsistence lifestyles. Most households have an income and, although this may be limited and shared among an extended family with only one or two in 
paid employment, they have the ability to purchase food. What they are in most immediate need of is improved sanitation and power supply.

South Tarawa is a significant urban conurbation with a population far in excess of the capacity of its existing infrastructure. This is not usual in many developing countries where the growth of urban centres runs ahead of the government's ability to provide a full range of public services for the ever-increasing population. As with the investment in upgrading Tuvalu's main airport it is telling that the international donor community is also investing in Kiribati, but on an even larger scale. Chris Comerford is the Team Leader for the South Tarawa Sanitation Improvement Sector Project. He is responsible for an extremely ambitious development aimed at vastly improving the freshwater provision and sewage treatment works of South Tarawa. The Asian Development Bank manages this project with the majority of the estimated US $\$ 22$ million budget being supplied by the Australian government. It has a twenty-year 'road map' to completion, again suggesting long-term commitment. Comerford is in no doubt that despite some environmental challenges posed by climate change and sea-level rise the donor community is committed to maintaining Tarawa, and therefore the territorial and sovereign integrity of Kiribati for the foreseeable future.

Donor agencies' contributions towards projects such as the one above can be attributed to a variety of motivations. They may be purely altruistic, or have elements of self-interest. The political rhetoric surrounding the international aid sector rarely highlights self-interest. This was reflected in the interviews with representatives of these agencies in Kiribati. Yet, unlike in Tuvalu, here there was an open acknowledgement that neither the governments of Australia or New Zealand would actively seek to relocate 100,000 I-Kiribati. While no causal connection was explicitly made the impression given was that investing in projects that would enable and encourage these islanders to remain where they are would be highly preferable to the mass migration alternative. Given only a relatively few islanders appear to be actively seeking permanent settlement in either Australia or New Zealand this is something of a moot point. Despite this it is worth noting as it adds a further dimension to the discourse on climate change and relocation that is overlooked in the 'single story'.

Ben Namikin of the Kiribati Climate Action Network provided significant insights from, an NGO perspective. At the time of interviewing he had recently returned from the UNFCCC CoP18 meeting in Doha. He noted that the official government delegation for Kiribati had a very low-key presence at this meeting compared to previous years where President Tong had led the delegation and received a great deal of international media coverage. Although not going as far as to say the President had boycotted this year's negotiations Namikin felt that it was a signal of Pacific island governments disillusionment with climate change negotiations. The Copenhagen Cop15 of 2009 was seen as a missed opportunity to seriously address the issue of greenhouse gas emissions. As with earlier respondents noted above, Namikin highlighted the significance of the discourse at these negotiations shifting from mitigation to adaptation measures. His view was that negotiations at this level were, if not meaningless, then certainly not achieving the required progress quickly enough. For him, perhaps unsurprisingly given his position, the focus should be on the NGO and civil society actors who were working at both the sub-state 
community level and also developing international networks such as the one he belongs to. This was not a complete dismissal of the role of the state, as they remain the most powerful players in the international community and control the largest budgets. Rather it was a view that two decades on from the Rio Earth Summit government negotiations had proceeded at a 'glacial pace while glaciers melted'. For Namikin any meaningful progress is more likely to take place with community engagement, education and action.

The outer island of Abaiang has a total population of an estimated 5-6,000. This is roughly equivalent to the population of Tuvalu's capital island, but Abaing is significantly larger than Funafuti and the population is spread over a dozen villages of varying sizes. All of these villages maintain traditional practices, although some have solar-powered electricity and access to limited water facilities. There is a twice-weekly light aircraft service to Tarawa, which takes around twenty minutes, and irregular boat services, which take two to three hours travel time. As such this community retains many of the characteristics of I-Kiribati lifestyles as practiced for many generations. Yet they are also within relatively easy reach of the main urban centre. The close proximity of Tarawa and Abaiang means that there is a greater level of interaction than there would be to some of the more remote outer islands, which have no air service and take several days to get to by ferry. The ferry service is notoriously unreliable with breakdowns and delays in delivery of spare parts meaning that travellers can be marooned on the outer islands for several weeks. Abaiang was chosen as the main island for conducting interviews in part because of the practicalities of reaching, and returning, from it. More importantly though was the level of awareness that the residents of these villages would have with regard to life on Tarawa as many of them would have either visited there themselves, or would be in regular contact with family members who were living there yet often returned to Abaiang.

As with the interviews conducted with outer islanders in Tuvalu those on Kiribati had their own individual experiences and stories, yet also shared a remarkable sense of community. They recounted evidence of environmental degradation, but tempered this by suggesting that only some of this could be accounted for by climate change and sea-level rise. Abaiang is larger than most of the atolls of Tuvalu with only a small number of construction projects, such as wharves and jetties, that may impact on beach degradation and other forms of coastal erosion. Therefore it is relatively straightforward to assess which areas have been impacted by such construction and which have been impacted solely by the action of wind and waves. There is evidence of both in various parts of the atoll. When questioned about the impacts of climate change and how to adapt to them few cited these as a reason to relocate. Rather they wished to understand better the reasons for these changes, to avoid practices which led to these changes (if locally induced) and to seek assistance in offsetting the most negative aspects of environmental degradation. Relocation was seen as something that was discussed elsewhere rather then in the local communities. Residents were aware of this external discourse but, as with the Tuvaluan respondents, they were somewhat dismissive of it and, in some case, appeared resentful that such views were being promoted by those with what they saw as a very limited understanding of Abaiang.

\section{Conclusion}


By engaging at the community level in the outer islands of both Tuvalu and Kiribati a more accurate picture can be drawn of not only the impacts of climate change and sea-level rise but also how these are perceived, contextualised and responded to at the local level. External discourses tend to rely on scientific reports produced by bodies such as the Intergovernmental Panel on Climate Change, which are then reported in mainstream media with photographs and footage of the most extreme weather events occurring in the islands. This is not to deny the science of the IPCC reports or that the events filmed and broadcast did not take place. Yet, recalling Adichie's 'single story' these partial representation do not tell the full story.

This study has attempted to distil inputs from the Tuvaluan and Kiribati governments, representatives of key international aid donors, relevant NGOs and most importantly, members of the outer island communities who are so often discussed without their views and opinions being acknowledged and heard. The EU-USP Global Climate Change Alliance workshops were very well received in the outer island communities they engaged with. Feedback suggested that although other donor agencies and their consultants had visited these communities previously they tended to come with a pre-determined agenda and solutions to what they thought were the problems these communities were facing. The GCCA workshops were different in that although they were partially facilitated by USP staff they were predominantly managed and led by local in-country coordinators, conducted in the local language and had an information-gathering remit, rather then information dissemination and direction. In other words these were workshops both 'by the people and for the people'. The discourse that took place within these workshops was self-generated and self-reflective. It was often at odds with the externally generated discourse on climate change and relocation.

By highlighting the disjunction between the dominant international discourse on climate change and how this issue is perceived and experienced within Tuvalu and Kiribati, this work raises fundamental questions regarding the implications of the 'single story' of these islands. By placing the islanders at the centre of this analysis a more complex, holistic story has emerged. The dominant discourse is only a partial story. This risks leading to a partial understanding, a partial analysis, a partial diagnosis and the offering of partial solutions. The single story may be more straightforward to understand and communicate via mainstream media channels. If the single story is flawed then the challenges of climate change, and other relevant factors, will not be successfully addressed. To address these challenges requires engagement with the communities most impacted and to fully integrate their views into future policies.

\section{References}

Adger, W.N. and Barnett, J. (2009) 'Commentary: Four reasons for concern about adaptation to climate change', Environment and Planning A, 41, pp. 2800-2805. 
Adger, W.N., Lorenzoni, I. and O'Brien, K.L. (2009a) 'Adaptation now'. In Adger, W.N., Lorenzoni, I. and O'Brien, K.L. (eds) Adapting to Climate Change: Thresholds, Values, Governance. CUP: Cambridge, pp. 1-22.

Adger, W.N., Lorenzoni, I. and O'Brien, K.L. (eds) (2009b) Adapting to Climate Change: Thresholds, Values, Governance. CUP: Cambridge.

Adichie, C. (2009) The Danger of a Single Story, TED talk available at www.ted.com/talks/chimamanda_adichie the_danger_of_a_single_story.

(accessed 24/1/2013)

Appleyard, R. (1989) 'Migration and Development: Myths and Reality', International Migration Review, 23 (3) pp. 486-499

Ashe, J.W., Van Lierop, R., and Cherian, A. (1999) 'The role of the Alliance of Small Island States (AOSIS) in the negotiation of the United Nations Framework Convention on Climate Change (UNFCCC)', Natural Resources Forum, 23, pp. 209-220.

Australian Bureau of Meteorology and CSIRO (2011) Climate Change in the Pacific: Scientific Assessment and New Research (Volume 1: Regional Overview). Canberra, Australia: Australian Bureau of Meteorology and CSIRO.

Barnett, J. (2005) 'Titanic states? Impacts and responses to climate change in the Pacific Islands', Journal of International Affairs, 59, pp. 203-219.

Barnett, J. and Adger, N. (2003) 'Climate dangers and atoll countries', Climatic Change, 61, pp. 321-337.

Barnett, J. and Campbell, J. (2010) Climate Change and Small Island States: Power, Knowledge and the South Pacific. London: Earthscan.

Barnett, J. and O’Neill, S. (2010) 'Maladaptation', Global Environmental Change, 20, pp. 211-213.

Barnett, J. and O'Neill, S.J. (2012) 'Islands, resettlement and adaptation', Nature Climate Change, 2, pp. 8-10.

Bates, D.C. (2002) 'Environmental refugees? Classifying human migrations caused by environmental change', Population and Environment, 23 (5), pp. 465-477.

Bedford, R. and Bedford, C. (2010) 'International migration and climate change: A 
Post-Copenhagen perspective on options for Kiribati and Tuvalu', In: Burson, B. (editor) Climate Change and Migration: South Pacific Perspectives, Institute of Policy Studies, Wellington, New Zealand, pp. 89-134.

Bertram, G. and Watters, R (1985) 'The MIRAB economy in South Pacific microstates', Pacific Viewpoint, 26 (3) pp. 497-519.

Bertram G. 'The MIRAB model twelve years on', The Contemporary Pacific, 11 (1) pp. 105-38.

Betram G. 'The MIRAB economy in the twenty-first century', Asia Pacific Viewpoint, 47 (1) 1-13

Biermann, F. and Boas, I. (2008) 'Protecting climate refugees: The case for a global protocol', Environment, 50 (6), pp. 8-16.

Black, R. (2001) 'Environmental refugees: Myth or reality?', UNHCR Working Paper No. 34, UNHCR: Geneva.

Bogardi, J. and Warner, K. (2009) 'Here comes the flood', Nature Report Climate Change, 3 (January), pp. 9-11.

Bridges, K.W. and McClatchey, W.C. (2009) 'Living on the margin: Ethnoecological insights from Marshall Islanders at Rongelap Atoll', Global Environmental Change, 19 (2), pp. 140-146.

Brown, O. (2007) 'Climate change and forced migration: Observations, projections and implications', Thematic Paper for the Human Development Report 2007/2008, UNDP: Geneva and New York.

Climate Congress (2009) Conference Report, accessed at: http://www.climatecongress.ku.dk

Cohen, J. (2012) Globalization and Sovereignty: Rethinking Legality, Legitimacy and Constitutionalism, CUP: Cambridge.

Connell, J. (2003) 'Losing ground? Tuvalu, the greenhouse effect and the garbage can', Asia Pacific Viewpoint, 44, pp. 89-107.

Dijk, T. A. van (2008) Discourse and Power, Houndsmill: Palgrave. 
Dijk, T. A. van (2008) Discourse and Context: A Sociocognitive Approach, CUP: Cambridge

Dijk, T. A. van (2009) Society and Discourse: How Context Controls Text and Talk, CUP: Cambridge

Dunn, K.M. (2005) 'Interviewing', In: Hay, I. (editor) Qualitative Research Methods in Human Geography, Oxford University Press, Melbourne, pp. 79-105.

Farbotko, C. (2005) 'Tuvalu and Climate Change: Constructions of Environmental Displacement in the Sydney Morning Herald', Geografiska Annaler, 87, pp. 279293.

Farbotko, C. and Lazrus, H. (2012) 'The first climate refugees? Contesting global narratives of climate change in Tuvalu', Global Environmental Change, 22 (2), pp. 382-390.

Felli, R. (2012) 'Managing climate insecurity by ensuring continuous capital accumulation: 'Climate refugees' and 'climate migrants', New Political Economy, iFirst.

Furedi, F. (2007a) 'The changing meaning of disaster', Area, 39, pp. 482-489.

Furedi, F. (2007b) 'From the narrative of the blitz to the rhetoric of vulnerability', Cultural Sociology, 1, pp. 235-254.

Gemenne, F. (2010) 'Tuvalu, un laboratoire du changement climatique? [Tuvalu, a laboratory of climate change?]', Tiers Monde, 4 (204), pp. 89-107.

Government of Tuvalu (2012a) TeKaniva: Tuvalu Climate Change Policy 2012. Funafuti, Tuvalu: Government of Tuvalu.

Government of Tuvalu (2012b) Tuvalu National Strategic Plan for Climate Change and Disaster Risk Management 2012-2016. Funafuti, Tuvalu: Government of Tuvalu.

Hayward-Jones, J. (2010) 'Tuvalu', In: Shearer et al (editors) '2020 Vision: That sinking feeling', The Australian, 16 January 2010, 10. 
Howitt, R., Havnen, O. and Veland, S. (2012) 'Natural and unnatural disasters: Responding with respect for Indigenous rights and knowledge', Geographical Research, 50 (1), pp. 47-59.

Kälin, W. (2010) 'Conceptualising climate-induced displacement', In: McAdam, J. (editor), Climate Change and Displacement: Multidisciplinary Perspectives, Hart Publishing: Oxford, pp. 81-104.

Kelman, I. (2010) 'Hearing local voices from Small Island Developing States for climate change', Local Environment, 15 (7), pp. 605-619.

Lefale, P.F. (2010) 'Ua 'afa le Aso stormy weather today: Traditional ecological knowledge of weather and climate. The Samoa experience, Climatic Change, 100 (2), pp. 317-335.

Lyons, G.M. (1995) 'International organizations and national interests', International Social Science Journal, 47, 261-276.

Masquelier, A. (2006) 'Why Katrina's victims aren't refugees: Musings on a "dirty" word', American Anthropologist, 108 (4), pp. 735-743.

McAdam, J. (2011) 'Swimming against the tide: Why a climate change displacement treaty is not the answer', International Journal of Refugee Law, 23 (1), pp. 1-26.

McAdam, J. (2012) Climate Change, Forced Migration and International Law, Oxford: OUP

McNamara, K.E. (2008) 'Pragmatic discourses and alternative resistance: Responses to climate change in the Pacific', Graduate Journal of Asia-Pacific Studies, 6 (2), pp. 33-54.

McNamara, K.E. (2009) 'Voices from the margins: Pacific ambassadors and the geopolitics of marginality at the United Nations', Asia Pacific Viewpoint, 50 (1), pp. 1-12.

McNamara, K.E. and Gibson, C. (2009) "We do not want to leave our land': Pacific ambassadors at the United Nations resist the category of climate refugees', Geoforum, 40 (3), pp. 475-483.

Mimura, N., Nurse, L., McLean, R.F., Agard, J., Briguglio, L., Lefale, P., Payet, R. and Sem, G. (2007) Small Islands, in M.L. Parry, O.F. Canziani, J.P. Palutikof, P.J. 
van der Linden and C.E. Hanson (eds.), Contribution of Working Group II to the Fourth Assessment Report of the Intergovernmental Panel on Climate Change, 2007. CUP: Cambridge, pp. 687-716.

Mortreux, C. and Barnett, J. (2009) 'Climate change, migration and adaptation in Funafuti, Tuvalu’, Global Environmental Change, 19, 105-112.

Myers, N. (1993) 'Environmental refugees in a globally warmed world', Bioscience, 43 (11), 752-761.

Myers, N. (1995) Environmental Exodus: An Emergent Crisis in the Global Arena, Climate Institute: Washington.

Najam, A., Huq, S. and Sokona, Y. (2003) 'Climate negotiations beyond Kyoto: Developing countries concerns and interests', Climate Policy, 3, 221-231.

Nelson, D.R. (2011) 'Adaptation and resilience: Responding to a changing climate', Wiley Interdisciplinary Reviews - Climate Change, 2, 113-119.

Parry, M.L., Canziani, O.F., Palutikof, J.P., van der Linden, P.J. and Hanson, C.E. (2007) Climate Change 2007: Impacts, Adaptation and Vulnerability. Contribution of Working Group II to the Fourth Assessment Report of the Intergovernmental Panel on Climate Change. CUP: Cambridge.

Parry, M., Lowe, J. and Hanson, C. (2009) 'Overshoot, adapt and recover', Nature, 458, 1102-1103.

Patel, S. (2006) 'A sinking feeling', Nature, 440, 734-736.

Piguet, E. (2008) 'Climate change and forced migration', New Issues in Refugee Research, Research Paper No. 153, Geneva: UNHCR.

Preston, B., Suppiah, R., Macadam, I. and Bathols, J. (2006) Climate Change in the Asia Pacific Region: A Consultancy Report Prepared for the Climate Change and Development Roundtable. Aspendale, Australia: CSIRO.

Renaud, F., Dun, O., Warner, K. and Bogardi, J. (2011) 'A decision framework for environmentally induced migration’, International Migration, 49 (S1), 5-29.

Shibuya, E. (1996) 'Roaring mice against the tide: The South Pacific islands and 
agenda-building on global warming', Pacific Affairs, 69, 541-555.

Smith, J.B., Schneider, S.H., Oppenheimer, M., Yohe, G.W., Hare, W., Mastrandrea, M.D., Patwardhan, A., Burton, I., Corfee-Morlot, J., Magadza, C.H.D., Füsser, H-M., Pittock, A.B., Rahman, A., Suarez, A., van Ypersele, J-P. (2009) 'Assessing dangerous climate change through up update of the Intergovernmental Panel on Climate Change (IPCC) reasons for concern', Proceedings of the National Academy of Sciences, 106, 4133-4137.

Smith, R and McMurray, C. (2000) Diseases of Globalisation, London: Earthscan

Stal, M. and Warner, K. (2009) 'The way forward: Researching the environment and migration nexus', UNU-EHS Research Brief, UNU-EHS, Bonn.

Winchester, H.P.M. (2005) 'Qualitative research and its place in human geography', In: Hay, I. (editor) Qualitative Research Methods in Human Geography, Oxford University Press: Melbourne, pp. 3-18. 